\title{
PERFORMANCE OF HORIZONTAL WATER-IN-GLASS EVACUATED TUBE SOLAR COLLECTORS
}

\author{
Daniel E. Thomas \\ MCC Bangladesh, GPO Box 785, Dhaka 1000, Bangladesh. \\ Current affiliation: SIM Bangladesh, GPO 8123, Dhaka 1216, Bangladesh. \\ *Corresponding author E-mail: dthomas@umn.edu
}

\begin{abstract}
Water-in-glass evacuated tube solar collectors are widely used in two main configurations: (1) a single row of tilted tubes connected to a header tank, and (2) two rows of horizontal tubes on either side of a central manifold. Published studies on water-in-glass collectors have been focused almost entirely on the former, commonly used for domestic water heating applications. This study considers the latter type, which is well suited to larger solar water heating applications. Experimental data from outdoor testing demonstrates a good fit to the ISO 9459-2 expression for collector performance. This daily heat gain model is used in simulations to illustrate sizing and design applications.
\end{abstract}

Keywords: Solar, Evacuated tube, Water-in-glass, Thermal performance, Outdoor testing

\section{INTRODUCTION}

Evacuated tube solar collectors have grown to dominate the solar water heating market in China, accounting for $93 \%$ of the installed solar heating capacity in $2012^{1}$. By 2009 , the annual production of evacuated tubes in China was 350 million, or 15 million collector units, representing $95 \%$ of the solar collector market ${ }^{2}$. These evacuated tubes have a concentric glass tube construction, with vacuum in the annular space and the selective solar absorbing surface on the outside of the inner tube. For pressurized systems, the evacuated glass tube is typically fitted with a heat pipe or metal U-tube to contain the heat transfer fluid. But the most common collectors in China heat water directly within the inner tube, relying on natural circulation to move heat out of the tubes. In these water-in-glass collectors, the tubes are sealed to a tank or manifold with a rubber seal, and the seal limits the allowable operating pressure.

The most common collector configuration for domestic solar water heating in China is a single row of tubes with the open end tilted up and fitted into a storage tank (T-type, Figure 1). For larger water heating systems, the most commonly used collector has two rows of horizontal tubes connected to opposite sides of a central manifold (H-type, Figure $2)^{2}$. Water is pumped through the central manifold, but circulation within tubes is buoyancy-driven.

Performance testing of water-in-glass evacuated tube collectors is covered by Chinese standard GB/T 18708 , a test of total daily heat output, similar to ISO $9459-2^{3-5}$. Although the H-type collector type is a pump-though collector, obtaining steady-state thermal performance, such as defined in ISO 9806, is complicated by the large internal volume. ISO 98062013 is explicitly not applicable to collectors having storage that is not seperable from the collector ${ }^{6}$. However, the equivalent Chinese standard, GB/T 17581 , is used for water-in-glass collectors as well as evacuated tube collectors with heat pipes or U-tubes 7,8 .

Thermal performance of evacuated tube collectors is evaluated based on the collectable radiation incident on the aperture or absorber surface. Calculation of the solar radiation incident on these cylindrical tube surfaces is more involved than that of a flat plate collector, being dependant on incidence angle and collector geometry, such as tube spacing. Theoretical analysis of the solar radiation incident on evacuated tube collectors was first presented by Beekley and Mather, G. R. ${ }^{9,10}$. Barrett et al. ${ }^{11}$ used a modification of the standard flat plate collector model to predict the performance of a evacuated tube collector. Two transmittance absorbtance terms $(\tau \alpha)$ are used for the transverse and longitudinal directions, in place of the single $\tau \alpha$ used with flat plate collectors. This incidence angle modifier varies between evacuated tube collectors because of differences in collector geometry, and must be measured for each collector. Shah and Furbo ${ }^{12}$ developed a theoretical model for performance of vertically oriented evacuated tube collectors. In order to estimate the collectible radiation for any of the common evacuated tube collector configurations, Tang et al. ${ }^{3,13}$ developed a detailed mathematical model covering horizontal and tilted tubes with and without a diffuse reflector backing.

Numerical and experimental investigation of flow patterns within water-in-glass evacuated tube collectors have been largely focused on the common T-type configuration with a single row of tubes connected to a header storage tank. Work relevant to the H-type collector with horizontal tubes includes Morrison et al. ${ }^{14}$, who developed correlations for natural circulation flow within tubes over a diffuse reflector. Shah and Furbo ${ }^{15}$ studied the H-type collector, examining the flow within horizontal evacuated tubes using CFD simulations. Their results showed higher efficiencies for shorter tube lengths 
and inlet flow rates of $0.4-3 \mathrm{~kg} / \mathrm{min}$. For the highest flow rate simulated, $10 \mathrm{~kg} / \mathrm{s}$, almost all the fluid flowed directly through the manifold, with very little flowing out into the tubes. However, variations in efficiency were small, and the collector performed well in all configurations simulated.

The objective of the work presented here is to experimentally evaluate the thermal output of the $\mathrm{H}$ type collector. This collector was identified as the most economical option for providing solar heat for handmade paper driers used in Bangladesh, of the type documented by Hjort and Thomas ${ }^{16}$.

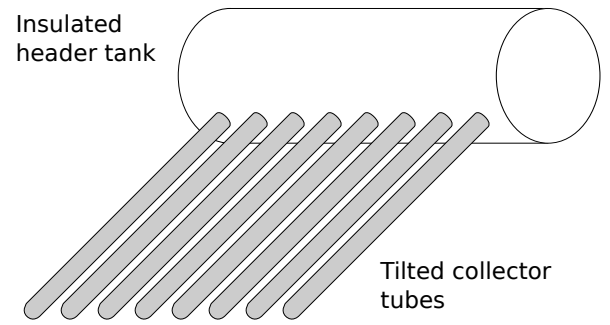

Figure 1. Common 'T-type' collector, with tilted evacuated collector tubes connected to an insulated header tank.

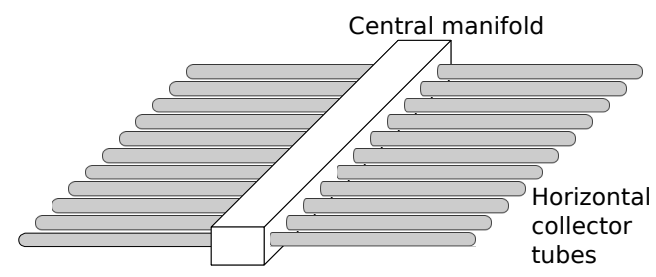

Figure 2. Common 'H-type' collector, with a two rows of horizontal collector tubes connected to a tilted central manifold.

Table 1. Evacuated tube collector specifications.

\begin{tabular}{lc}
\hline Number of tubes & 50 \\
Tube outer diameter & $0.058 \mathrm{~m}$ \\
Tube inner diameter & $0.047 \mathrm{~m}$ \\
Tube overall length & $1.820 \mathrm{~m}$ \\
Tube absorber length & $1.685 \mathrm{~m}$ \\
Tube spacing & $0.075 \mathrm{~m}$ \\
Gross area & $6.358 \mathrm{~m}^{2}$ \\
Aperture area & $4.887 \mathrm{~m}^{2}$ \\
Absorber area & $3.960 \mathrm{~m}^{2}$ \\
Collector azimuth & $0^{\circ}$ \\
Collector slope & $38.5^{\circ}$ \\
\hline
\end{tabular}

\section{APPARATUS AND METHOD}

A 50-tube commercial collector from China, with the specifications shown in Table 1, was monitored over a period of 6 months. Figures 3 and 4 show the layout and instrumentation. Ambient and fluid temperatures were measured with precision thermistors $\left( \pm 0.5^{\circ} \mathrm{C}\right)$. Total insolation was measured with an Apogee SP-110 pyranometer $( \pm 1 \%$ repeatability, $\pm 5 \%$ absolute accuracy). A shaded strip pyranometer, also using an SP-110, was used to measure diffuse insolation. Flow was measured with a Gems FT-330 Hall Effect turbine flowmeter (calibrated for $\pm 1 \%$ accuracy). The collector water was recirculated, and heat was removed using a water-to-air heat exchanger. All data was measured at 5 second intervals and recorded at 1 minute intervals with a Campbell Scientific CR10X datalogger (accuracy $\pm 0.05 \%$ of full scale range).

The collector performance was monitored over a period from March to September 2011, at the test location in Bogra, Bangladesh (24⒌ $\left.{ }^{\prime} \mathrm{N} 89^{\circ} 22^{\prime} \mathrm{E}\right)$. In addition to scheduled shutdown periods, the data contained shorter gaps due to power failure and instrument malfunction. Short gaps of 10 minutes or less were filled in using interpolated values; days with missing data exceeding 10 minutes were considered unsuitable for including in the analysis. The range of total daily insulation for the data set of 122 days is shown in Figure 5. This period includes the hot, dry season (March-April), and the monsoon rainy season (June-August). The collector was monitored for dust build-up during the course of the test and cleaned in the early morning as necessary, daily during the dry season.

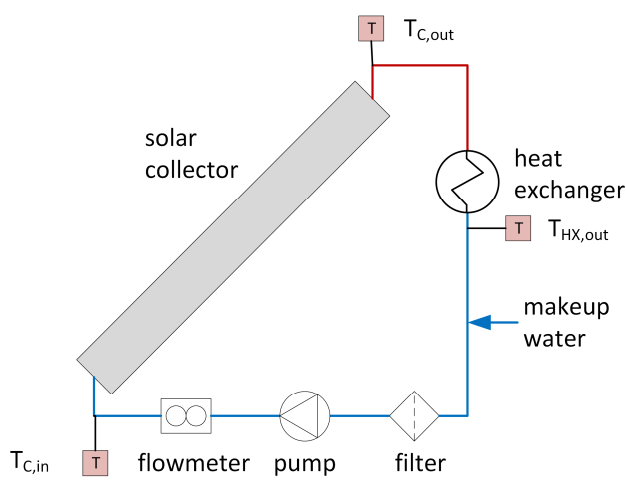

Figure 3. Layout and instrumentation used for the collector performance test.

Water was circulated through the collector at 5.5 $\mathrm{kg} / \mathrm{min}$. This flow rate is on the high side of the optimum flow rates indicated by Shah and Furbo's results ${ }^{15}$ for tubes with an inner diameter of $37 \mathrm{~mm}$. Flow within the manifold is laminar, with Reynolds number estimated to be below 1500 thoughout the test period. 


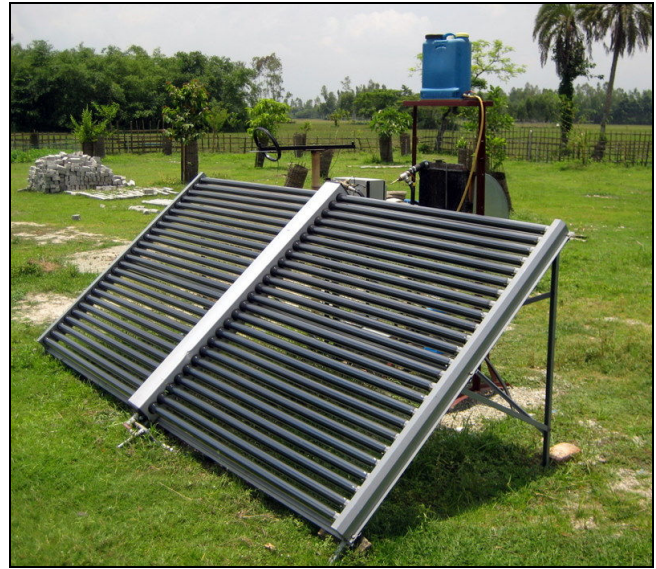

Figure 4. The test apparatus during performance testing in Bogra, Bangladesh.

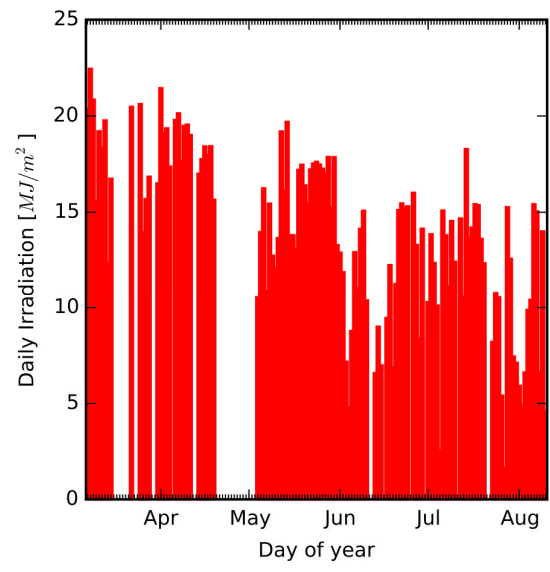

Figure 5. Total daily incident radiation for the 122 day dataset used in this study.

\section{ANALYSIS AND RESULTS}

As described in the ISO 9459-2 standard ${ }^{5}$, the collector heat output is correlated to the total incident radiation, $\mathrm{H}$, and the difference between the ambient temperature, $\mathrm{T}_{\mathrm{amb}}$, and collector inlet temperature, $\mathrm{T}_{\mathrm{in}}$, using the following relation:

$$
\mathrm{Q}=\mathrm{a}_{1} \mathrm{H}+\mathrm{a}_{2}\left(\mathrm{~T}_{\mathrm{amb}}-\mathrm{T}_{\mathrm{in}}\right)+\mathrm{a}_{3}
$$

Radiation incident on the tube absorber surface is calculated from measured total horizontal and diffuse insolation using the method outlined by Tang et al. ${ }^{13}$. The calculation accounts for the tube geometry, spacing, and orientation. Regression analysis, shown in Figure 6 , shows a close fit $\left(R^{2}=\right.$ 0.988 ) and yields the following constants:

$$
\begin{aligned}
& \mathrm{a}_{1}=3.835 \\
& \mathrm{a}_{2}=0.324 \\
& \mathrm{a}_{3}=-0.031
\end{aligned}
$$

Instantaneous collector efficiency, as defined by ISO 9806, was reported for a H-type water-in-glass collector by Zhiqiang ${ }^{17}$. This efficiency was measured by the Institute for Solar Technology (SPF), in Rapperswil, Switzerland, in 1996. The Tsinghua Solar collector tested was a 50-tube model with smaller tubes $(37 \mathrm{~mm}$ outer diameter and 1200 $\mathrm{mm}$ length) than those used in this study. The interior volume of the Tsinghua collector is estimated at about $70 \mathrm{~L}$, i.e. less than half of the $145 \mathrm{~L}$ volume of the collector used in this study. Because of our larger interior volume, an instantaneous efficiency model was not attempted. Any such result would be dependent on factors such as the water flow rate and collector slope, and would be of limited value.

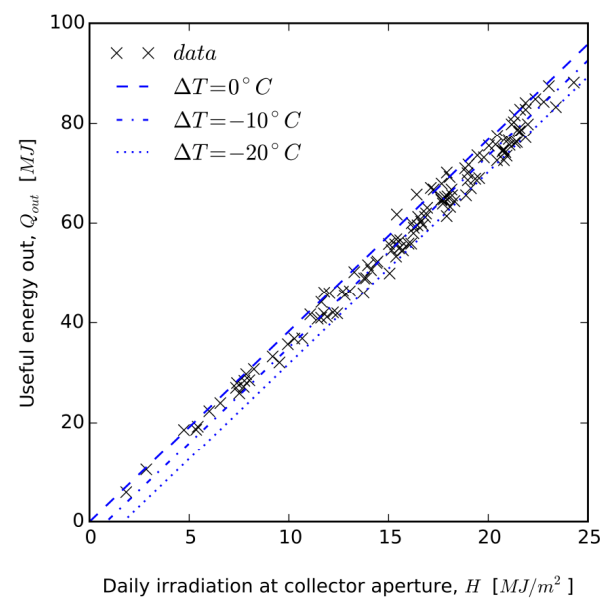

Figure 6. Collector heat output, showing single variable regression analysis.

The collector time constant was measured using the same apparatus. The collector was allowed to heat up and fluid temperatures stabilized over solar noon. Then a step change was made to the inlet flow, reducing the inlet water temperature from $56.0^{\circ} \mathrm{C}$ to a steady $30.9 \pm 0.3^{\circ} \mathrm{C}$. The time constant was measured as the time required for the system response to change by $63.2 \%$ from the initial output temperature to steady state value. The measured time constant of 22 minutes is consistant with large volume of fluid contained in the collector $(145 \mathrm{~L})$. Typical time constant values for flat plate collectors are in the range of $1-2$ minutes.

\section{SIMULATIONS}

The model of daily collector heat output given above is useful for basic collector array design and sizing. To simulate the collector performance for a particular site, the following simulations use typical meteorological year (TMY) weather data provided by the Solar and Wind Energy Resource Assessment initiative ${ }^{18}$ and solar energy analysis code from the 
solpy project ${ }^{19}$. Beam and diffuse components of the hourly TMY solar radiation are used to interpolate minute data for each day of the year. The solar radiation incident on the collector absorber surface is then calculated using the method described by Tang et al. ${ }^{13}$ in minute increments. The collector heat output is then calculated from the daily total insolation using the relation given above. An average $\left(\mathrm{T}_{\mathrm{amb}}-\mathrm{T}_{\mathrm{in}}\right)$ of $-10^{\circ} \mathrm{C}$ is assumed.

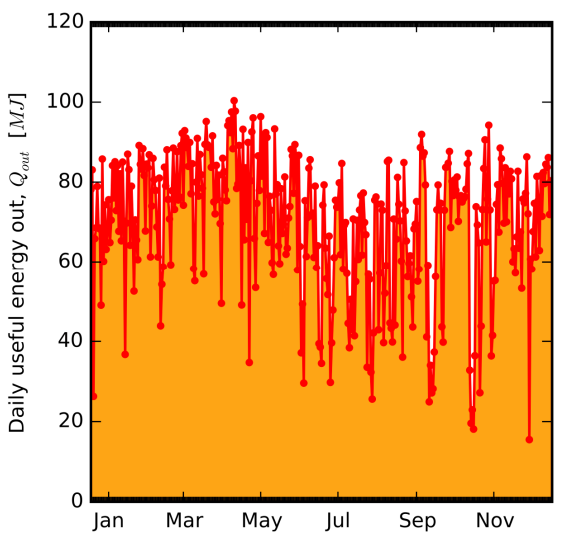

Figure 7. Total daily collector heat output simulated using typical meteorological year data for Bogra, Bangladesh

Figure 7 shows the total daily collectable energy from the collector tested over the course of a year. The effect of varying the collector slope is shown in Figure 8, for the same collector and TMY data for the Bogra location tested above. Results indicate that a lowering collector slope from $38.5^{\circ}$ as in the experimental setup to about $10^{\circ}$ would give an increase in annual heat output of about $6.5 \%$.

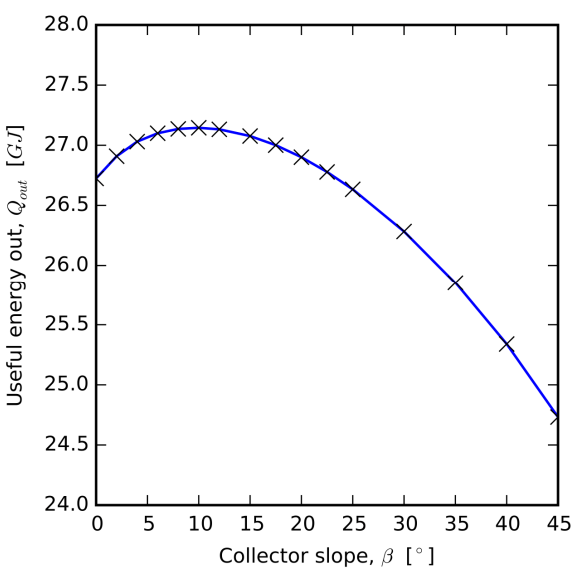

Figure 8. Total annual collector heat output with varying collector slope angle.

\section{CONCLUSIONS}

The daily useful energy gain of a 'H-type' water-inglass evacuated tube collector can be effectively expressed using a correlation to total incident radiation and temperature differential, as given in the ISO 9459-2 standard. The daily energy gain model provides a good fit to experimental data from outdoor testing, and is a useful model while more detailed models are unavailable. Because of the large interior volume and time constant of this type of collector, no expression for instantaneous efficiency was obtained. The daily useful energy gain model was used with solpy code to simulate annual energy gain.

\section{ACKNOWLEDGMENTS}

The experimental work described in this paper was conducted at the Appropriate Technology Center, a program of Mennonite Central Committee Bangladesh. Assistance from colleagues Nathan Charles, Rana Masud, Mickael Hjort, and Lokhon Paul is gratefully acknowledged, as is funding from the Mennonite Central Committee.

\section{REFERENCES}

1. Mauthner, F. and Weiss, W., 2014, "Solar Heat Worldwide." Technical report, International Energy Agency, Gleisdorf, Austria.

2. Tang, R., Yang, Y., and Gao, W., 2011, "Comparative studies on thermal performance of water-in-glass evacuated tube solar water heaters with different collector tilt-angles." Solar Energy, 85(7):1381-1389,

doi:10.1016/j.solener.2011.03.019.

3. Tang, R., Yang, Y., and Yu, Y., 2012, "On the Suitability of Test Method of GB/T 18708 for Waterin-Glass Evacuated Tube Solar Water Heaters." In 2012 Asia-Pacific Power and Energy Engineering Conference, pages 1-4. IEEE, doi:10.1109/APPEEC.2012.6307038.

4. Chinese standard GB/T 18708, 2002, “Test methods for thermal performance of domestic solar water heating systems."

5. International Standards Organization, 1995, "ISO 9459-2: Solar heating - Domestic water heating systems. Part 2: Performance prediction of solar-only systems." ISO, Geneva.

6. International Standards Organization, 2013, "ISO 9806: Solar energy - Solar thermal collectors - Test methods." ISO, Geneva.

7. Zhifeng, S., Bin, L., Tao, H., Zhong, L., and Airong, F., 2009, "Studies." In Proceedings of ISES World Congress 2007, Goswami, Y., and Zhao, Y., eds, Springer Berlin. doi:10.1007/978-3-540-759973.

8. Chinese Standard GB/T 1758, 2007, "Evacuated 
tube solar collectors."

9. Beekley, D. C., and Mather, G. R., 1975, “Analysis and experimental tests of high performance tubular solar collectors." ISES75: Solar Use Now - A Resource for People, pp 220-221, ISES, Los Angeles, CA.

10. Beekley, D. C. and Mather, G. R., 1978, "Analysis and Experimental Tests of a HighPerformance Evacuated Tubular Collector." NASA technical report.

11. Barrett, A.L., Beckman, W.A., and Duffie, J.A., 1988, "Thermal modeling of evacuated tubular collectors." Solar '88: Proceedings of the 1988 Annual Meeting, Coleman, M. J., ed, p 505-510. ASES, Cambridge, MA.

12. Shah, L.J. and Furbo, S., 2004, "Vertical evacuated tubular-collectors utilizing solar radiation from all directions.” Applied Energy, 78(4):371-395, doi:10.1016/j.apenergy.2003.10.004.

13. Tang, R., Gao, W., Yu, Y., and Chen, H., 2009, "Optimal tilt angles of all-glass evacuated tube solar collectors.” Energy, 34(9):1387-1395, doi:10.1016/j.energy.2009.06.014.

14. Morrison, G., Budihardjo, I., and Behnia, M., 2007, "Natural circulation flow through water-inglass evacuated tube solar collectors." Solar Energy, 81(12):1460-1472,

doi:10.1016/j.solener.2007.03.002.

15. Shah, L.J. and Furbo, S., 2007, "Theoretical flow investigations of an all glass evacuated tubular collector." Solar Energy, 81(6):822-828, doi:10.1016/j.solener.2006.09.007.

16. Hjort, M., and Thomas, D.E., 2014, "Performance of a Solar Paper Drier for Small-Scale Paper Sheet Production." Journal of Mechanical Engineering, 44(1):6-9.

17. Zhiqiang, Y., 2005, "Development of solar thermal systems in China." Solar Energy Materials and Solar Cells, 86(3):427-442, doi:10.1016/j.solmat.2004.07.012.

18. SWERA, 2015, "Global Horizontal Irradiance data" http://swera.unep.net

19. Charles, N. and Thomas, D.E., 2015, solpy, https://github.com/nrcharles/solpy/ 